TARNOWSKIE STUDIA TEOLOGICZNE 35 (2016) NR 2, S. 41-50

http://dx.doi.org/10.15633/tst.2104

Jan Mazur OSPPE ${ }^{1}$

UNIWERSYTET PAPIESKI JANA PAWŁA II W KRAKOWIE

\title{
Oblicze fenomenu kidults
}

W ponowoczesności zjawisko kidults nie jest jakąś osobliwością. Opinia publiczna niemal permanentnie bombardowana jest przez bardziej lub mniej jawne ideologie. Szczególny wpływ na społeczeństwo wywiera poprawność polityczna, genderyzm, homoideologia czy chociażby skrajny ekologizm. Rozpowszechnianie tych ideologii można, przynajmniej od strony badawczej, traktować jako konkretne fakty i zjawiska z uwagi na ich skutki kulturowe i cywilizacyjne. Również pewnym zjawiskiem kulturowym jest fenomen określany mianem kidults. Jednak tym się on różni od wspomnianych już genderyzmu czy poprawności politycznej, że nie sterują nim określone siły, grupy nacisku, jakieś wpływowe ośrodki czy środowiska, ale jest konsekwencją ogólnych przemian cywilizacyjnych.

\section{Kim są kidults?}

Nietrudno zauważyć, że angielskie słowo kidults składa się z dwóch słów: kid - „dziecko” i adult - „dorosły”. Termin kidults po raz pierwszy został użyty na łamach „The New York Times” w 1985 roku. Autor tego terminu, Peter Martin, zastosował go na określenie ludzi, którzy korzystając z doświadczeń dorosłości, jednocześnie - jak dzieci - uciekają od jej trudów i zobowiązań. Są wprawdzie dorośli, ale pod wieloma względami ich poglądy i postawy kryją w sobie niechęć do dorosłości. Innymi słowy, kidults to ci, którzy usiłują powrócić do bezpiecznych lat dziecięcych, do szczęśliwej nieświadomości.

${ }^{1}$ Jan Mazur, ks. dr hab., prof. UPJPII - zakonnik pauliński, kierownik Katedry Polityki Społecznej Wydziału Nauk Społecznych Uniwersytetu Papieskiego Jana Pawła II w Krakowie, wykładowca katolickiej nauki społecznej w wsD Zakonu Paulinów. W kręgu jego zainteresowań naukowych znajdują się polityka społeczna, katolicka nauka społeczna, dialog społeczny, antropologia chrześcijańska i etyka polityki. Jest autorem licznych publikacji z zakresu uprawianych przez siebie dyscyplin. 
Pragną - jak pisze Martin - uwolnić się od odpowiedzialności za świat, marząc o prawie do układania elementów w swoisty, niepowtarzalny zestaw, który budzi zdziwienie i dobre samopoczucie ${ }^{2}$.

Interesująca jest charakterystyka kidults zamieszona przed laty w „Rzeczpospolitej”. Można przeczytać w niej między innymi, że „kidult to osoba w średnim wieku, która uczestniczy w kulturze młodzieżowej i otacza się gadżetami o takim charakterze. Tak mówi definicja. W praktyce to określenie przypomina worek bez dna, do którego można wrzucić wszystko, a każdy, kto przekroczył magiczną trzydziestkę, znajdzie w sobie coś z «dzieciorosłego». Może to być fascynacja Harry Potterem, kolekcja żelaźniaków na półce, minispódniczka z kolorowych falbanek, bluza $\mathrm{z}$ kapturem na grzbiecie poważnego prezesa, kucyki zamiast trwałej ondulacji, liliowy samochód w srebrne kwiatki"3.

Wskazując na oryginalność tego zjawiska, autor tekstu w „Rzeczpospolitej” nie bez racji zauważył: „Chodzi o to, że kiedyś nie wypadało robić pewnych rzeczy w pewnym wieku, a dziś już nikogo to nie dziwi. Chociaż rasowy kidult może wydawać się śmieszny. Tak jak niektórym wydaje się Kuba Wojewódzki, który mógłby być dziadkiem, a jest bożyszczem nastolatków"4.

Frank Furedi, angielski socjolog, autor wielu publikacji o tym zjawisku, mówi o całym pokoleniu kidulds, którego charakterystycznymi znakami są: 1. zachowania konsumenckie; 2. styl ubierania; 3. powrót do literatury dziecięcej (np. o Harrym Potterze); 4. dziecięce gadżety; 5. podtrzymywanie dystansu do świata; 6. spontaniczność zachowań; 7. zabawy5. W sumie można nawet mówić o „dziecinnieniu” całej kultury euroatlantyckiej. W czym się to przejawia? Ludzie dorośli nierzadko rezygnują z poszukiwań twórczych na niwie wysiłku intelektualnego, komunikację ograniczają do powierzchownego kontaktu medialnego, jak również uzależniają się od przekazywanych im treści, przyjmując je bezkrytycznie i bezrefleksyjnie.

Wydaje się, iż ów trent występujący w kulturze europejskiej i północnoamerykańskiej, a więc w krajach przeważnie rozwiniętych i zamożnych, odpowiada fantazji literackiej związanej z postacią Piotrusia Pana. Jak

\footnotetext{
2 Por. J. Mazur, „Kidults” as a phenomenon of postmodernity, „Молодь і ринок” (Дрогобич) $2015 \mathrm{nr} 7$ (126), s. 143.

Kidults w średnim wieku, „Rzeczpospolita” z 7.11.2007, http://www.rp.pl/artykul/67388. html (8.05.2015).

4 Kidults $w$ średnim wieku...

5 Cyt. za: M. Gębicka-Andrian, Dzieci Piotrusia Pana, „Wprost” 2006 nr 22, s. 69.
} 
wiadomo, chodzi o klasyczne dzieło literatury dziecięcej (opowiadanie o Piotrusiu Panu) autorstwa Jamesa Matthew Barriego. Piotruś Pan był małym chłopcem. Jego marzeniem było całe życie pozostać dzieckiem, aby móc żyć dziecięcą fantazją, niekończącą się zabawą, i - oczywiście - aby nie podejmować wyzwań i obowiązków wynikających z dorosłości. Opowiadanie ma - rzecz jasna - swoją długą i ciekawą fabułę. Czytelnik dowiaduje się, że to pragnienie Piotrusia Pana było tak silne, iż rzeczywiście nigdy nie dorósł. Na zawsze pozostał małym chłopcem, niedojrzałym do ojcostwa i do założenia rodziny.

No cóż, to co niegdyś było tylko przedmiotem wyobraźni literackiej (Barrie wydał swoją książkę w 1902 roku), dziś można by określić jako społeczny przejaw syndromu Piotrusia Pana. Na przykład Francesco Cataluccio, autor książki: Niedojrzałość. Choroba naszych czasów, uważa, że syndrom ten stanowi chorobę, która toczy współczesny świat. Ludzie zachowują się tak, jakby nie chcieli być dorosłymi, albowiem nie chcą wziąć odpowiedzialności za świat, w którym żyją. Nie chcą wziąć odpowiedzialności nawet za swoje własne życie. Wystarczy im imitowanie wzorców niedojrzałej popkultury. Potrafią zadowolić się takimi przeżyciami, jak przygoda czy jakakolwiek podróż. Na ogół zdaniem Cataluccia - tacy ludzie nie stawiają pytań, nie myślą, nie martwią się o przyszłość, nie traktują poważnie niczego i nikogo, zadowoleni są ze swoich złudzeń, poszukując niekończącej się zabawy i przyjemnych chwil.

Przywołany autor zauważa jednak, że ludzie naznaczeni syndromem Piotrusia Pana, będący pokoleniem kidults, mogą przyjmować postawę „zdziecinnienia” również dlatego, że społeczeństwo zapewnia im poczucie bezpieczeństwa. Sugeruje on, i to chyba nie bez racji, że zjawisko kidults jest problemem głównie społeczeństw bogatych, zamożnych.

Jakkolwiek by było, nietrudno jednak zauważyć, że zjawisko kidults występuje także w krajach mniej zamożnych, w których ma ono przyczyny ekonomiczne. Młodzi ludzie odwlekają czas dojrzałości i samodzielności, bo jest im wygodnie być na utrzymaniu rodziców. Według Eurostatu, blisko 2,5 miliona Polaków w wieku od 25 do 34 lat wciąż mieszka w rodzinnym domu. Natomiast dwie trzecie młodych Europejczyków ciągle opiera swoje materialne utrzymanie na wsparciu ze strony rodziców. Z kolei we Włoszech 70 procent tzw. mammoni, czyli mężczyzn w wieku 30-35 lat wciąż mieszka $\mathrm{w}$ domu rodzinnym ${ }^{6}$.

6 Por. A. Bojar, M. Mistrzak, Maminsynek polski, „Wprost” 2010 nr 43, s. 6o-61. 
Jest to problem także Wielkiej Brytanii, Francji, Niemiec czy nawet Stanów Zjednoczonych i Japonii. Kraje te zmagają się z problemem ludzi młodych, którzy w wieku dorosłym wciąż pozostają na utrzymaniu rodziców. Większość takich kidults nawet nie może opuścić rodziców, bo nie studiuje, nie ma pracy, nie ma żadnego pomysłu na życie ${ }^{7}$. Sami siebie określają jako: „silnie związani z rodzicami”, „zadowoleni z życia”, „dobrze ubrani i dobrze wyglądający”, „niemający partnera”, „niepragnący zbytnio samodzielności”. Natomiast otoczenie postrzega ich jako „silnie związanych z rodzicami”, „zależnych od rodziny”, „konserwatywnych”, „słabych psychicznie”, „stojących z boku”.

Kidults mają problemy przede wszystkim $\mathrm{z}$ właściwymi relacjami międzyludzkimi. Szczególnie widoczne to jest w próbach nawiązywania relacji przyjaźni z innymi. Psychologia wyróżnia u dzieci trzy poziomy w rozwoju i podtrzymywaniu przyjaźni: poziom czy stopień „zysków i strat”, poziom normatywny i poziom empatyczny. Otóż Piotruś Pan zatrzymuje się zwykle na pierwszym poziomie. Jest to przyjaźń charakterystyczna dla rozwoju dziecka do lat ośmiu. Opiera się na wspólnym wykonywaniu tych samych czynności, zamieszkiwaniu w sąsiedztwie, podobieństwie oczekiwań. Piotruś Pan nie jest zainteresowany ani poziomem normatywnym, ani empatycznym. Jego przyjaźń trwa tak długo, jak długo przyjaciele zaspokajają jego pragnienia i potrzeby, jak długo mają podobne zainteresowania, a więc gdy „zyski” z tych relacji są większe aniżeli „straty”. Jeśli normy i zasady, którymi przyjaciele się kierują, zaczynają być niepodobne do jego przekonań, to przyjaźń ustaje, po prostu zanika.

\section{Kidults w sferze społecznej}

Ludzie obciążeni mentalnością kidults są obecni także w sferze życia politycznego. Wtedy owa mentalność staje się groźna, bo wszyscy, chcąc nie chcąc, narażeni są na jej wpływ. Dla wielu polityków priorytetem staje się

Należy w tym miejscu zauważyć, że nie wszyscy dwudziestolatkowie lub trzydziestolatkowie mieszkający wspólnie z rodzicami, będący na ich utrzymaniu, zasługują na kwalifikację kidults. W Polsce wielu $\mathrm{z}$ nich pozostaje $\mathrm{w}$ tej sytuacji z powodu bezrobocia. Chętnie by się wyzwolili z tego rodzaju zależności. Nierzadko decydują się na migrację zarobkową, która jednak odznacza się wysokim stopniem uciążliwości życiowej. Tak więc w Polsce zjawisko kidults wykazuje tylko częściowe podobieństwo do tego, co można zaobserwować w krajach wysokorozwiniętych.

8 Cyt. za: A. Zwoliński, Tato, gdzie jesteś?, Kraków 2015, s. 125. 
troska o wygląd, dobór emocji, potrzeba wywarcia dobrego wrażenia, ale to jeszcze nie wszystko. Najbardziej niebezpieczne zdaje się być to, że kidults w działaniu politycznym nie przejawiają perspektywicznego myślenia. Liczy się dla nich chwila obecna. Odcinają się od przeszłości, traktując ją jako niepotrzebny balast, i nie zastanawiają się zbytnio nad przyszłością. Zupełnie podobnie jak dzieci.

Wydaje się, że ukrytą infantylizację w sferze politycznej kryje w sobie postawa tzw. leminga społecznego czy politycznego (kategoria, którą z upodobaniem posługują się dziś socjologowie i politolodzy). Infantylizacja lemingów politycznych jest niekiedy zatrważająca. Jeden z czytelników „Gazety Polskiej Codziennie”, w tekście zatytułowanym: Lemingi łykną wszystko, napisał: „Wiem, co mówię, bo mam syna leminga. Ma 34 lata i gdy mówię mu, że na przykład nie będzie miał emerytury, to on atakuje PiS. Ja swoje, a on uparcie swoje... Tłumaczę mu: człowieku, nie o PiS-ie mówię, lecz o Twojej przyszłości, o to się martwię! Bo za 10-15 lat pewnie przyjdziesz do mnie po prośbie... Usiąść i płakać nad tym pokoleniem"9.

Kim jest leming polityczny? Samo określenie słowne zdaje się być trafne, bo nawiązuje do nazwy gryzonia, który ma podobno skłonności samobójcze. Leming polityczny to człowiek, który bezkrytycznie przyjmuje podawane informacje. Bezrozumnie konsumuje informacje medialne i bezwiednie daje się uwodzić propagandzie. Szkodzi przez to sobie i tym wszystkim, z którymi dzieli własny los.

Niekiedy pokolenie kidults przyjmuje postawy wręcz karykaturalne, co wyraża się w niemal obsesyjnym kulcie młodości. W wielu krajach zamożnych do młodego pokolenia nie zaliczają się już tylko nastolatkowie czy dwudziestolatkowie, ale także trzydziestolatkowie, a nawet czterdziestolatkowie. Interesujące są wyniki jednej z ankiet przeprowadzonej w USA i Wielkiej Brytanii. Ponad dwie trzecie ankietowanych nastolatków napisało, że ich rodzice robią wszystko, by w oczach swoich dzieci i ich kolegów uchodzić za "równych kumpli” (ang. cool mamy). Dlatego zakładają młodzieżową biżuterię, robią sobie tatuaże, noszą biodrówki, chętnie uczestniczą we wspólnych imprezach ${ }^{10}$.

9 Cyt. za: M. Janicki, W. Władyka, Strategia leminga, http://www.polityka.pl/tygodnikpolityka/kraj/1528687,1,kim-jest-polityczny-leming.read (8.05.2015).

${ }^{10}$ Por. P. Kozłowska, Dorosłe dzieci, „Przekrój” 2006 nr 14, s. 56-58, cyt. za: A. Zwoliński, Tato, gdzie jesteś?, s. 125 . 
Można bez trudu skonstatować, że pokolenie kidults uparcie kojarzy życie z dzieciństwem i młodością, co wiąże się z osłabieniem czy nawet zanikiem etyki obowiązku i pracy, przy jednoczesnym hołdowaniu etyce hedonistycznej. Hedonizm ma to do siebie, że za bezwzględny priorytet życiowy przyjmuje przyjemność. A samo życie, kojarzone z dzieciństwem i młodością, usiłuje sprowadzić do radości i zabawy. Kidults owładnięci hedonizmem, a także egoizmem, dorosłość traktują jako nudę i stagnację.

Trudno nie przyznać racji autorowi „Rzeczpospolitej”, który napisał: „Na zbiorowym niedorastaniu najbardziej korzystają globalni producenci. Świadczy o tym obecność na rynku luksusowych gadżetów przypominających akcesoria dziecięce - designerskie zabawki, różowe telefony komórkowe, sprzęt AGD w kształcie stworków, animowane filmy o treści nieprzeznaczonej dla dzieci i moda odzieżowa. Są to drogie przedmioty, ale kidulta na nie stać. W Polsce na tęsknotę za młodością nakłada się także nostalgia za PRL. Dzisiejsi trzydziestolatkowie chętnie wracają do dobranocek z dzieciństwa, ówczesnych komiksów, smaku lodów bambino. Trudno wprawdzie w każdym miłośniku przygód Kapitana Żbika upatrywać wyrosłego z kultury konsumpcyjnej kidulta. Młodzi Polacy, którzy dorastają w nowych czasach, z pewnością już niedługo doczekają się swojej socjologicznej szufladki”"1.

\section{Chrześcijaństwo wobec kidults}

Jaką postawę wobec pokolenia kidults może czy nawet powinno przyjąć chrześcijaństwo? Omawiane zjawisko jest wszakże niełatwym wyzwaniem dla duszpasterstwa. Otóż wydaje się, że w relacjach z pokoleniem kidults trzeba unikać skrajności, chociażby takich, których przykład dali w starożytności dwaj filozofowie: Demokryt i Heraklit. Warto o tym wspomnieć tytułem ciekawostki. Demokryt, ilekroć pomyślał o ludzkim życiu, nie mógł się powstrzymać od śmiechu, natomiast Heraklit zawsze na myśl o życiu ludzkim płakał. Wydaje się, że w praktyce pastoralnej problemy życiowe pokolenia kidults nie mogą być ani lekceważone (kwitowane śmiechem) ani też zbytnio wyolbrzymiane jakoby nic w tej dziedzinie nie dało się zmienić na lepsze.

Chrześcijaństwo dysponuje skutecznymi środkami do przezwyciężania tego wszystkiego, co w fenomenie kidults stanowi egzystencjalne zagrożenie, kwestionuje dojrzałą dorosłość, zaciemnia świadomość nadprzyrodzonej

${ }^{11}$ Kidults $w$ średnim wieku... 
godności człowieka, pogrąża go w marazmie duchowym oraz fałszuje obraz i podobieństwo Boga w człowieku. Najważniejszym środkiem jest moc czynnej, dojrzałej miłości chrześcijańskiej, realizowanej w relacjach międzyosobowych.

W tym miejscu warto przywołać kilka oczywistych skądinąd prawd, których uwzględnienie może prowadzić do skutecznego przełamania syndromu Piotrusia Pana. Można by je ująć w następujące punkty:

1. W relacjach przyjaźni należy koniecznie wyjść z poziomu „zysków i strat" (o czym była już mowa powyżej), by wejść na wyższe poziomy. Najpierw na poziom normatywny (ważne jest w nim respektowanie tych samych wartości, norm i zasad), by następnie osiągnąć dojrzały stan przyjaźni - jej poziom empatyczny (zakłada on wzajemne zrozumienie, zaufanie i wspólne zainteresowania).

2. Jednakże osiągnięcie poziomu empatycznego musi być oparte na określonej antropologii, która daje jasną odpowiedź na pytanie o to, kim jest człowiek. Takiej odpowiedzi dostarcza właśnie objawienie chrześcijańskie.

3. Wejście na poziom empatyczny w relacjach z innymi ludźmi, będący oznaką dojrzałości, w szczególności zakłada, by drugiego człowieka zawsze traktować osobowo. Wydaje się, że człowiek zdziecinniały, przysłowiowy Piotruś Pan, ma szansę odkryć osobowe bogactwo swojego człowieczeństwa, jeśli najpierw odkryje osobę w drugim człowieku (odkrycie, że drugi człowiek jest osobą, prowadzi do uświadomienia sobie, że „ja również jestem osobą" - teza personalistyczna).

4. Dla dojrzałej i odpowiedzialnej postawy społecznej ważne jest, by Piotruś Pan w drugim człowieku widział zarówno bliźniego (a więc kogoś bliskiego, z kim jest w bezpośredniej osobowej relacji), jak i członka społeczności (a więc kogoś, kto podobnie jak on jest odpowiedzialny za los społeczności, za jej dobro wspólne). Obydwa aspekty są ważne, gdy w grę wchodzi praktykowanie miłości chrześcijańskiej, która wyzwala od egoizmu. Intuicja wiary podpowiada w tym miejscu, że „kochać człowieka jako bliźniego" oznacza tyle, co docierać do niego aktami miłości bezpośredniej. Natomiast kochać człowieka jako członka społeczności, to docierać do niego z miłością pośrednio poprzez struktury życia społecznego, instytucje, społeczności, wspólnoty czy grupy.

5. Ważny jest styl, ogólne nastawienie, które wiąże się praktykowaniem miłości. Kidults zwykle nie zdają sobie sprawy z tego, że ich relacja miłości jest nie tyle „świadectwem miłości”, co przede wszystkim „miłością 
świadectwa". Tymczasem powinna być i jednym, i drugim. W tym układzie niezwykle ważne jest odpowiednie rozłożenie akcentów. Świadectwo miłości jest niczym innym, jak umiłowaniem konkretnego człowieka, który pozostaje w osobowej relacji, zaś miłość świadectwa jest jakby umiłowaniem samej miłości. Oba te elementy muszą ze sobą harmonizować. Jeśli bowiem występuje tylko „umiłowanie człowieka”, to miłość będzie jakimś poświęceniem się, altruizmem czy altruistycznym poświęceniem i niczym więcej. Z kolei położenie akcentu wyłącznie na "umiłowaniu miłości” (ktoś kocha dla samego kochania, bo lubi kochać) powoduje, że miłość staje się instrumentalizacją drugiego człowieka. Jest on jakby okazją do praktykowania miłości. W rzeczywistości może być tak, że bardziej miłowana jest miłość jako idea czy praktyka (np. dzieło miłosierdzia), aniżeli sam człowiek.

6. Na koniec niepodobna nie przywołać manifestu miłości chrześcijańskiej, jakim jest słynny Pawłowy Hymn o miłości w Pierwszym Liście do Koryntian. Dla kidults tekst ten może być wspaniałym przewodnikiem pozwalającym na powrót do dojrzałej i odpowiedzialnej dorosłości ${ }^{12}$.

Przytoczone powyżej opinie na temat zjawiska kidults i jego pobieżna interpretacja to tylko głos w dyskusji, która wciąż trwa na poziomie rozpoznania problemu. Niestety, stopień owego rozpoznania nadal wydaje się mało zadowalający. Brakuje interdyscyplinarnej, pogłębionej refleksji na ten temat. Oby niniejszy szkic problemu pobudził badaczy z obszaru szeroko rozumianych nauk społecznych, zwłaszcza socjologów, do twórczych analiz i poszukiwań w zakresie problematyki kidults!

\section{Bibliografia}

Barrie J. M., Piotruś Pan i Wendy, tłum. M. Rusinek, Kraków 2014.

Bojar A., Mistrzak M., Maminsynek polski, „Wprost” $2010 \mathrm{nr} 43$, s. 6o-61.

Brooks K., Nothing sells like teen spirit: the commodification of youth culture, w: Youth cultures: texts, images, and identities, eds. K. Mallan, S. Pearce, Westport 2003, s. 1-16. Cataluccio F. M., Niedojrzałość. Choroba naszych czasów, tłum. S. Kasprzysiak, Kraków 2006.

Gębicka-Andrian M., Dzieci Piotrusia Pana, „Wprost” 2006 nr 22, s. 68-70.

12 Por. J. Mazur, „Kidult” as a phenomenon of postmodernity, „Молодь і ринок” (Дрогобич) $2015 \mathrm{nr} 7$ (126), s. 145-146. 
Janicki M., Władyka W., Strategia leminga, http://www.polityka.pl/tygodnikpolityka/kraj/1528687,1,kim-jest-polityczny-leming.read (8.05.2015).

Kidults w średnim wieku, „Rzeczpospolita” z 7.11.2007, http://www.rp.pl/arty$\mathrm{kul} / 67388 . \mathrm{html}$ (8.05.2015).

Kozłowska P., Dorosłe dzieci, „Przekrój” 2006 nr 14, s. 56-58.

Mazur J. OspPE, „Kidults” as a phenomenon of postmodernity, „Молодь і ринок” (Дрогобич) $2015 \mathrm{nr} 7$ (126), s. 143-146.

Noxon Ch., Rejuvenile: Kickball, Cartoons, Cupcakes, and the Reinvention of the American Grown-up, 2006 (online book preview).

Seligman M. E. P., Walker E. F., Rosenhan D. L., Psychopatologia, tłum. J. Gilewicz, A. Wojciechowski, Poznań 2003.

Semka P., Kidulci z Platformy, „Wprost” 2008 nr 8, s. 26-27.

Stare dzieci: młodzi Polacy nie chca się usamodzielniać, https://www.google.pl/?gws_rd=ssl\#q=Pokolenie+bamboccioni (8.05.2015).

Śliwiński P. J. o., Zdziecinnienie - przekleństwo, marzenie czy metoda?, w: Dzieckiem podszyte. Rzecz o dzieciństwie, red. A. Regiewicz, Zabrze 2000, s. 53-58.

Walulik A., Dorosłość kształtowana przez dziecinstwo, w: (Bez)radność wychowania...?, red. Z. Marek i M. Madej-Babula, Kraków 2007, s. 79-91.

Zwoliński A. ks., Kidults - dorosłe dzieci, http://www.katolik.pl/24557,416.druk?s=1 (8.05.2015).

Zwoliński A. ks., Tato, gdzie jesteś?, Kraków 2015.

\section{Streszczenie}

Zjawisko kulturowe kidults zostało rozpoznane stosunkowo niedawno. Jest ono konsekwencją postępujących zmian cywilizacyjnych. Samo słowo kidults składa się z dwóch słów: „dziecko” i „dorośli”. Po raz pierwszy zostało użyte na łamach „The New York Times” w 1985 roku. Peter Martin zastosował go na określenie ludzi, którzy korzystając z doświadczeń swojej dorosłości, uciekają od jej trudów i zobowiązań. Są wprawdzie dorośli, ale pod wieloma względami ich poglądy i postawy kryją w sobie elementy zdziecinnienia.

Tekst zawiera trzy części, których tytuły wskazują na jego treść: 1. Kim są kidults?, 2. Kidults w sferze społecznej, 3. Chrześcijaństwo wobec kidults. Można skonstatować, że dziś istnieje całe pokolenie kidults. Tacy ludzie uparcie kojarzą życie z dzieciństwem i młodością. Niestety, wiąże się to z osłabieniem czy nawet zanikiem etyki obowiązku i pracy, przy jednoczesnym hołdowaniu etyce hedonistycznej. 
Wydaje się, że chrześcijaństwo dysponuje skutecznymi środkami do przezwyciężania tego wszystkiego, co w fenomenie kidults stanowi egzystencjalne zagrożenie, kwestionuje dojrzałą dorosłość, zaciemnia świadomość nadprzyrodzonej godności człowieka, pogrąża go w marazmie duchowym i fałszuje obraz i podobieństwo Boga w człowieku. Najważniejszym środkiem jest moc czynnej miłości chrześcijańskiej, realizowanej w relacjach międzyosobowych.

\section{Słowa kluczowe}

kidults, dorosłość, dziecinność, młodość, dojrzała osobowość, leming polityczny, hedonizm, egoizm

\section{Summary}

\section{The face of the phenomenon of kidults}

The kidults phenomenon was recognized relatively recently. It is a consequence of progressive civilization changes. The word kidults is a combination of two words: kid and adult. It was first used in "The New York Times" in 1985. Peter Martin applied it to describe people who take advantage of the experience of adulthood, while escaping from its hardships and responsibilities. They are in fact adults, but in many respects their views and attitudes contain elements of infantilization.

The text consists of three parts, and the content is revealed in each title: 1 . Who are kidults? 2. Kidults in the social sphere 3. Christianity and kidults. It may be noted that today there is a whole generation of kidults. Such people stubbornly associate life with childhood and adolescence. Unfortunately, this involves the weakening or even the disappearance of the ethic of work and responsibility, while a hedonistic ethic is espoused.

It seems that Christianity has the means to effectively overcome that which in the kidults phenomenon constitutes an existential threat, disputes mature adulthood, obscures awareness of human dignity, plunges a person into spiritual apathy and distorts the image and likeness of God in man. The most important measure is the active power of Christian love, expressed in interpersonal relationships.

\section{Keywords}

kidults, adulthood, childishness, youth, mature personality, political lemming, hedonism, selfishness 